\title{
Phenetic and Genetic Variability of Continental and Island Populations of the Freshwater Copepod Mastigodiaptomus ha Cervantes, 2020 (Copepoda): A Case of Dispersal?
}

\author{
Adrián Cervantes-Martínez ${ }^{1, *}$, Martha Angélica Gutiérrez-Aguirre ${ }^{1}$, Eduardo Suárez-Morales ${ }^{2}$ and Sarahi Jaime ${ }^{1}$ \\ 1 Unidad Académica Cozumel, Universidad de Quintana Roo, Av. Andrés Quintana Roo, Calle 11 con calle \\ 110 sur s/n, C.P. 77600 Cozumel, Mexico; margutierrez@uqroo.edu.mx (M.A.G.-A.); 1518305@uqroo.mx (S.J.) \\ 2 Unidad Académica Chetumal, El Colegio de la Frontera Sur, Av. Centenario km 5.5, \\ C.P. 77014 Chetumal, Mexico; esuarez@ecosur.mx \\ * Correspondence: adcervantes@uqroo.edu.mx
}

\section{check for} updates

Citation: Cervantes-Martínez, A.; Gutiérrez-Aguirre, M.A.;

Suárez-Morales, E.; Jaime, S. Phenetic and Genetic Variability of Continental and Island Populations of the Freshwater Copepod Mastigodiaptomus ha Cervantes, 2020 (Copepoda): A Case of Dispersal? Diversity 2021, 13, 279. https:// doi.org/10.3390/d13060279

Academic Editor: Bert W. Hoeksema

Received: 12 May 2021

Accepted: 13 June 2021

Published: 21 June 2021

Publisher's Note: MDPI stays neutral with regard to jurisdictional claims in published maps and institutional affiliations.

Copyright: (C) 2021 by the authors. Licensee MDPI, Basel, Switzerland. This article is an open access article distributed under the terms and conditions of the Creative Commons Attribution (CC BY) license (https:// creativecommons.org/licenses/by/ $4.0 /)$.

\begin{abstract}
The diversity of freshwater zooplankton is still little known in Mexico, particularly in reference to insular zooplankton communities. Diaptomid copepods (Crustacea: Copepoda: Calanoida) are a widespread group worldwide, and Mexico harbours high diaptomid diversity. Based on a recent sampling of freshwater zooplankton on a Caribbean Island of Mexico, we present the first record of a diaptomid copepod from an island freshwater ecosystem. It shows the well-known tendency of Neotropical diaptomids to have restricted distributional patterns and high levels of endemism. The species recorded, Mastigodiaptomus ha (Cervantes-Martínez, 2020) appears to have a restricted distribution in the Yucatan Peninsula (YP), and the island as well. In order to explore potential differences between the island and continental populations of this species, its phenetic and genetic diversity was analysed by performing morphological comparisons and also by exploring differences of the habitat conditions and genetic sequences (CO1 gene). Our analysis revealed a low (average $=0.33 \%$ ) genetic divergence between both populations; likewise, both the morphology and habitat conditions closely resemble each other in these two populations. The low genetic divergence between the continental and island populations of $M$. ha suggests an early common origin of the species in the geological history of the YP.
\end{abstract}

Keywords: barcoding; Calanoida; diaptomids; freshwater; insular water bodies; new record

\section{Introduction}

The diverse zooplankton community inhabiting the epicontinental and underground freshwater ecosystems of the Yucatan Peninsula (YP) can be largely constituted by calanoid copepods belonging to the most successful freshwater group; the family Diaptomidae. Diaptomids tend to have restricted distributional patterns, with many endemic species in the Neotropical region [1].

Mastigodiaptomus is one of the most diverse genera in Mexico, currently including 13 species. The genus is widely distributed in the Neotropical region, including the Caribbean islands, Central America, and areas of the Southern United States [2,3].

Recently, Gutiérrez-Aguirre et al. [3] described three new species of the genus from Mexico; Mastigodiaptomus cihuatlan (Gutiérrez-Aguirre, 2020), M. alexei (Elías Gutiérrez, 2020), and M. ha (Cervantes-Martínez, 2020). The latter was found in sinkholes (locally known as cenotes) in the northeastern continental zone region of the YP.

After 15 years of basic studies on the freshwater and anchialine zooplankton in Cozumel Island [4-6], this is the first report of a diaptomid copepod on a Mexican island. Previously, M. ha has been recorded in continental freshwater systems in the northnortheastern region of the YP [3]. In this study we analysed the phenetic and genetic distances between the island and continental populations, and specimens from the type 
locality of $M$. $h a$, adding new molecular barcodes revealing that, despite the fact that these two populations were isolated for over 8000-6000 years, they are phenotypically and genetically similar.

This work confirms that YP copepod fauna provides the best-known Mexican region for harbouring the greatest diversity of the Mastigodiaptomus species in Central America and the Caribbean region [2,3,7].

\section{Materials and Methods}

\subsection{Study Sites and Sampling Methods}

Cozumel Island is located off the northeastern coast of the YP, in the northwestern region of the Caribbean Sea (Figure 1) and, because of its area $\left(\sim 500 \mathrm{~km}^{2}\right)$, it is the third largest island in Mexico and the most populated. An $18 \mathrm{~km}$ wide channel separates it from the continental YP.

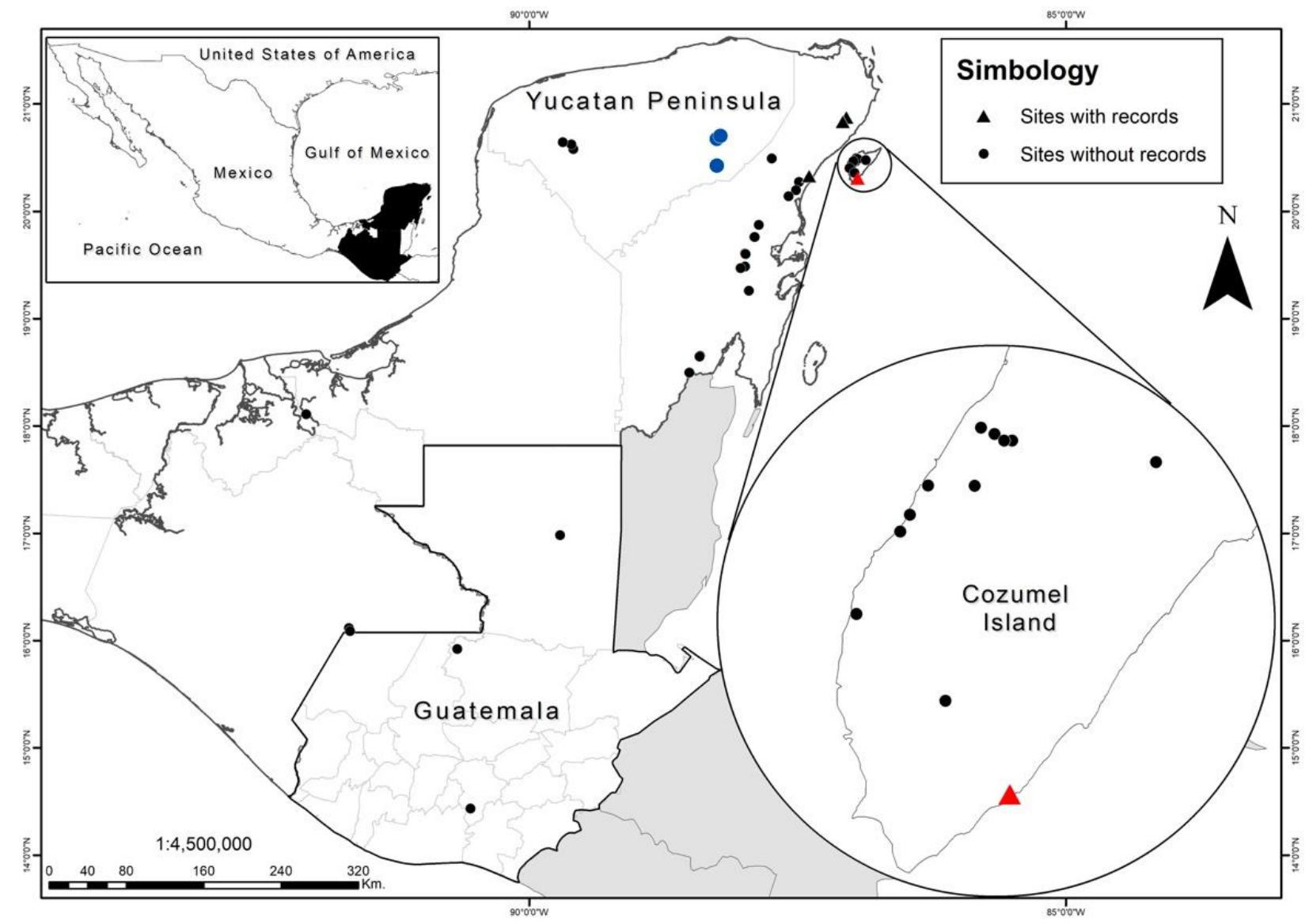

Figure 1. Collection sites for zooplankton samples in the YP, Mexico (2005-2020), where diaptomids are present. Black circles are negative records of Mastigodiaptomus ha; triangles are positive sites for records of $M$. $h a$. The red triangle is the place where the species was founded on Cozumel Island. Blue circles indicate probable presence of this species.

The YP is considered one of the largest karstic aquifers in Mexico and the world [8]; a system that includes Cozumel Island, which was once part of the continental YP geologic plate of the YP ( 25 Mya). Like all karstic aquifers, underground aquatic systems are extended (freshwater or anchialine); sinkholes and some superficial lagoons are the surface features of karstic environments $[9,10]$. Cozumel island has some similar aquatic systems to those mentioned before, but they differ in area, size, and depth [11,12].

\subsection{Zooplankton Analysis}

During the last 15 years, a systematic sampling of freshwater and anchialine zooplankton has been performed on the YP and Cozumel Island (Figure 1), with high zooplankton 
diversity and crustacean endemicity [4-6,13]. Water samples for biotic and abiotic variables were collected on the southern part of the island, after the atypical influence of tropical storms in September-October 2020 on Cozumel Island [14].

The species classification of Copepoda was performed according to the methods outlined by Elías-Gutiérrez et al. [15] and Suárez-Morales et al. [16], several specimens were compared with the recently described $M$. $h a$, inventoried in the north-northeastern region of the YP continental plate [3].

Then, the phenetic variability between the continental vs. island populations of $M$. ha was determined, considering the morphological, environmental, and geological features of the locations inhabited by the copepods. Chemical environmental variables, related to the ionic content, and temperatures were measured in situ with a professional-plus YS Datasonde ${ }^{\circledR}$ (Xylem Inc., Yellow Springs, OH, USA). The trophic status of these systems was determined by the chlorophyll $a$ concentration [9]. The sequence of the COI gene was used as evidence of the genetic variability between continental and insular populations of M. ha.

\subsubsection{Continental Populations Analysed}

1. Adult female holotype, dissected on semi-permanent slide (ECOCH-Z-10319), adult male allotype, dissected, mounted on semi-permanent slide (ECOCH-Z-10320), and 20 adult females and 20 males preserved in $96 \%$ ethanol and one drop of glycerine (ECOCH-Z-10321). Cenote 7 Bocas, Quintana Roo, Mexico, $20^{\circ} 52^{\prime} 36^{\prime \prime} \mathrm{N} ; 87^{\circ} 02^{\prime} 37^{\prime \prime} \mathrm{W}$, the type locality of Mastigodiaptomus ha.

2. Specimens obtained from Verde Lucero $\left(n=30\right.$, ECOCH-Z-10327; $20^{\circ} 52^{\prime} 09.57^{\prime \prime} \mathrm{N}$, $\left.87^{\circ} 04^{\prime} 37.52^{\prime \prime} \mathrm{W}\right)$ and Boca del Puma $\left(n=6\right.$, ECOCH-Z-10326; $\left.20^{\circ} 52^{\prime} 179^{\prime \prime} \mathrm{N}, 87^{\circ} 03^{\prime} 18^{\prime \prime} \mathrm{W}\right)$ in Quintana Roo, Mexico were also analysed.

\subsubsection{Cozumel Island Population}

Twenty-two adult females and 36 adult males from 25 Horas Lagoon $\left(20^{\circ} 18^{\prime} 39.7^{\prime \prime} \mathrm{N}\right.$, $86^{\circ} 56^{\prime} 14.2^{\prime \prime} \mathrm{W}$ ) (ECO-CH-Z-10539). The acronym ECOCH-CH-Z refers to the Zooplankton Reference Collection held at El Colegio de la Frontera Sur, Chetumal, Mexico.

The morphological variability between the two groups of populations was analysed with dissected and whole specimens using a compound Nikon Eclipse 50i microscope. Light microscopic images of variable features were captured with a Lumenera Infinity1 YIDT camera (Teledyne Lumenera, Ottawa, Canada) and arranged in Adobe Photoshop V. 6.0 following the current taxonomic standards for the genus Mastigodiaptomus $[2,17,18]$.

The DNA extractions of the COI gene, PCR products, and sequence alignment between populations were conducted following the methods of Ivanova et al. [19], Hebert et al. [20], Prosser et al. [21], and Elías-Gutiérrez et al. [22], in accordance with the protocols of the Barcoding Laboratory of Life (ECOSUR, Chetumal, Mexico). Two specimens from the type area, three from the Verde Lucero, and two from the Boca del Puma were considered the continental populations in the genetic analysis, and 28 specimens from the Cozumel population were all included.

Cluster analyses of these sequences were performed to obtain a graphic representation of the divergences among the specimens by using Molecular Evolutionary Genetics Analysis (MEGA X) software (MEGA Freeware, University of Pensilvania, Philadelphia, PA, USA).

Sequences were aligned to 600 base pairs (pb) with CLUSTAL W, and the Kimura 2 parameter (KP2) distance model was used to calculate the sequence divergences. Neighbourjoining (NJ) clusters were created with the gamma distribution model.

All sequences $>500 \mathrm{pb}$ were added to the public data dataset named Mastigodiaptomus, created in the Barcode of Life Data Systems portal (BOLDSYSTEMS, http:/ / boldsystems. org/index.php, accessed on 15 April 2021). In the dataset DOI: 10.5883/DS-MMASTIGO (The Barcode of Live Data System, University of Guelph, Guelph, Canada, accessed on 
15 April 2021), the individual sequences, trace files, collection data, and primer details are available.

\section{Results}

\subsection{Variability of Environmental, Genetic and Morphological Features}

Mastigodiaptomus $h a$ is a freshwater, free-living diaptomid copepod, that is apparently endemic to the north and northeastern zones of the YP. The aquatic ecosystems inhabited by this species showed the following environmental features: low elevations (13.2 \pm 6.0 masl), oligo-mesotrophic conditions $\left(\leq 0.70 \mathrm{mg} / \mathrm{m}^{3}\right.$ of chlorophyll $\left.a\right)$, low oxygen concentrations $(1.5 \pm 1.8 \mathrm{mg} / \mathrm{L})$, tropical climates $\left(26.8 \pm 1.9^{\circ} \mathrm{C}\right)$, freshwater $(0.7 \pm 0.2 \mathrm{ppt})$, low conductivities $\left(1396 \pm 559.2 \mu \mathrm{S} / \mathrm{cm}^{3}\right)$ (Table 1$)$, and physically the sinkholes where $M$. ha was recorded are type 2,3, and 4 sinkholes according to Hall [23] (Table 1).

Table 1. Limnological characteristics of the aquatic habitats inhabited by Mastigodiaptomus ha (Quintana Roo, Mexico). Elev = elevation $(\mathrm{masl}), \mathrm{T}=$ water temperature, $\mathrm{O}_{2}=$ dissolved oxygen $(\mathrm{mg} / \mathrm{L}), \mathrm{EC}=$ electrical conductivity $\left(\mu \mathrm{S} / \mathrm{cm}^{3}\right)$, Sal = salinity $(\mathrm{ppt}), \mathrm{TS}=$ trophic state.

\begin{tabular}{|c|c|c|c|c|c|c|c|c|}
\hline Place Name & Coordinates & Sinkhole Classification [23] & Elev & $\mathrm{T}$ & $\mathrm{O}_{2}$ & EC & Sal & TS \\
\hline Chemuyil & $\begin{array}{l}20^{\circ} 21^{\prime} 38.7^{\prime \prime} \mathrm{N} \\
87^{\circ} 23^{\prime} 98.1^{\prime \prime} \mathrm{W}\end{array}$ & $\begin{array}{l}\text { Vertical walls with wide aperture } \\
\text { (as a glass) }\end{array}$ & 10 & 29.2 & 4.6 & 2274 & 1.1 & Oligotrophic \\
\hline Verde Lucero & $\begin{array}{l}20^{\circ} 52^{\prime} 08.7^{\prime \prime} \mathrm{N} \\
87^{\circ} 04^{\prime} 37.5^{\prime \prime} \mathrm{W}\end{array}$ & $\begin{array}{l}\text { Vertical walls with wide aperture } \\
\text { (as a glass) }\end{array}$ & 18 & 24.7 & 1.8 & 1414 & 0.8 & Mesotrophic \\
\hline 7 Bocas & $\begin{array}{l}20^{\circ} 52^{\prime} 35.8^{\prime \prime} \mathrm{N} \\
87^{\circ} 02^{\prime} 37.5^{\prime \prime} \mathrm{W}\end{array}$ & $\begin{array}{l}\text { Cavern, with lateral entrance } \\
\text { leading to a chamber with water }\end{array}$ & 16 & 25.6 & 0.3 & 1365 & 0.7 & Oligotrophic \\
\hline $\begin{array}{l}\text { Boca del } \\
\text { Puma }\end{array}$ & $\begin{array}{c}20^{\circ} 52^{\prime} 17.9^{\prime \prime} \mathrm{N} \\
87^{\circ} 03^{\prime} 18^{\prime \prime} \mathrm{W}\end{array}$ & $\begin{array}{l}\text { Cavern, with lateral entrance } \\
\text { leading to a chamber with water }\end{array}$ & 18 & 26.3 & 0.7 & 1170 & 0.6 & Oligotrophic \\
\hline 25 Horas & $\begin{array}{l}20^{\circ} 18^{\prime} 39.7^{\prime \prime} \mathrm{N} \\
86^{\circ} 56^{\prime} 14.2^{\prime \prime} \mathrm{W}\end{array}$ & Superficial lagoon ("aguada") & 4 & 28.6 & 0.2 & 742 & 0.4 & Oligotrophic \\
\hline
\end{tabular}

This kind of aquatic ecosystem is common on the northern and the eastern fringe zones of the YP, where the most recent, highly permeable sediments (i.e., Miocene, Pliocene, and Quaternary) are widespread $[8,24]$. These regions are therefore dominated by underground currents or superficial lagoons that formed recently in geological time [8].

\subsection{Genetic Variability}

The consensus tree with the highest log likelihood is shown in Figure 2. The bootstrap percentages of trees, in which the associated taxa were clustered together, are shown next to the branches. The extended dendrogram displays that the four continental populations and one island population analysed showed one group with low genetic divergence: the BOLDsystems generated the BIN AAU1038 (The Barcode of Live Data System, University of Guelph, Guelph, Canada, accessed on 15 April 2021). The genetic divergence between populations was $0.33 \%$ on average (Table 2 ).

Table 2. Sequence divergence distribution at each taxonomic level examined. To avoid confusion, in this analysis continental vs. island specimens were labelled as two different species, Mastigodiaptomus ha vs. Mastigodiaptomus sp. (= M. ha-island population), to perform a comparison between the populations.

\begin{tabular}{cccccccc}
\hline Label & $\mathbf{N}$ & Taxa & Comparisons & Min Dist. & Mean Dist. & Max Dist. & SE Dist. \\
\hline $\begin{array}{c}\text { Within } \\
\text { species }\end{array}$ & 36 & 2 & 416 & 0.00 & 0.33 & 2.22 & 0.00 \\
\hline Within genus & 37 & 1 & 179 & 0.34 & 4.64 & 20.15 & 0.04 \\
\hline
\end{tabular}




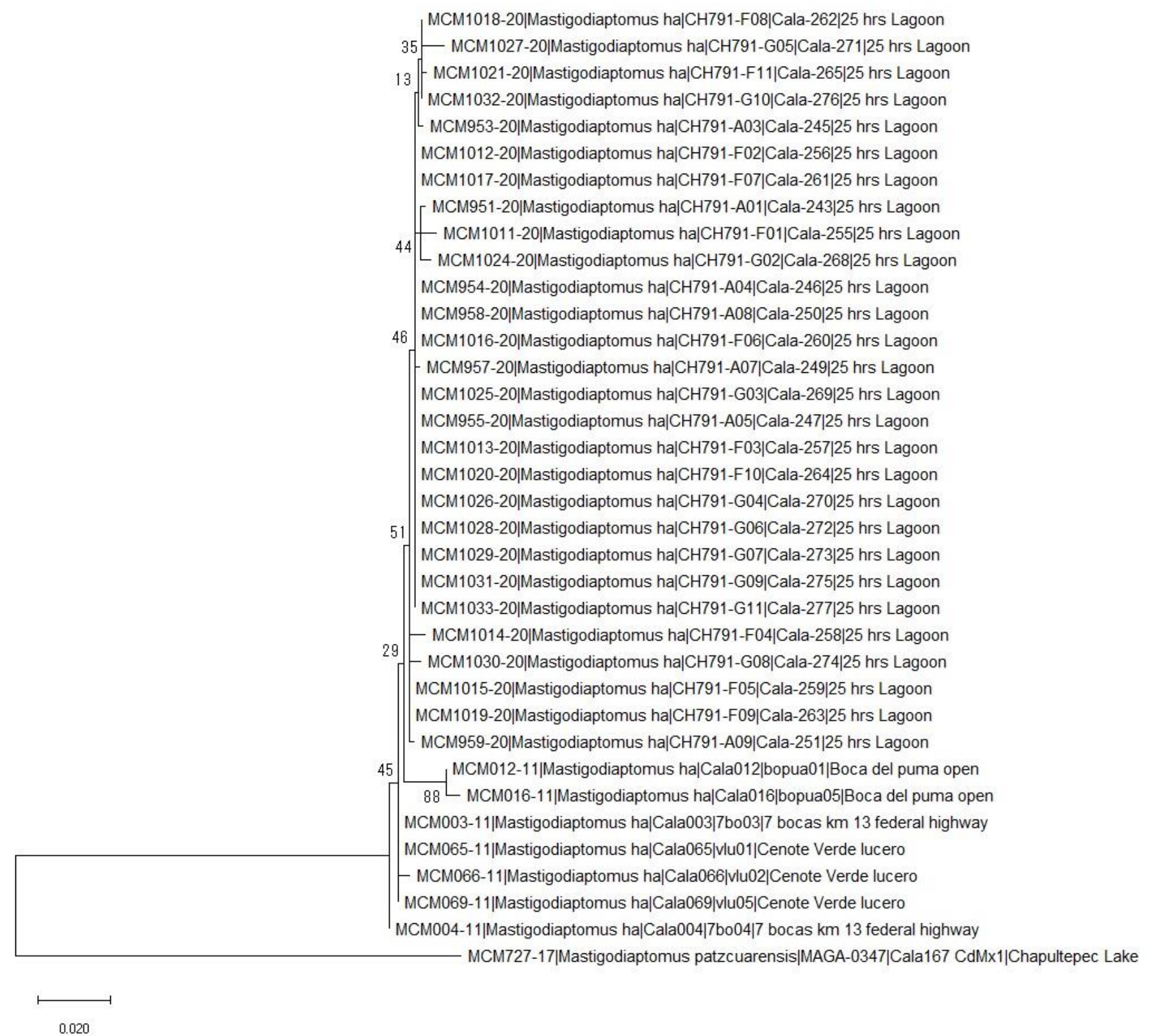

Figure 2. Analysis for Mastigodiaptomus ha (Quintana Roo, Mexico) with the maximum likelihood method to observe genetic relationships between continental and insular populations (1000 replicates), based on the COI gene. The scale length represents the percentage of genetic distance between branches.

The body sizes of specimens of the island population of $\mathrm{M}$. ha were larger than those of the continental population specimens; in the continental populations, the total body lengths were similar between females and males, ranging from 1.2 to $1.3 \mathrm{~mm}$; whereas the females of Cozumel island are larger (i.e., 1.6 to $1.78 \mathrm{~mm}, n=28$ ); males are also larger in the island population ( 1.45 to $1.5 \mathrm{~mm}, n=35$ ).

The rostral points shape was also variable in all the analysed continental and island populations: short with rounded points, medium-sized with rounded points or even, large and acute in females (Figure 3A-B). Whereas only $20 \%$ of the continental females bear a dorsal keel-like process on the fifth prosomite, all the examined females of the island population ( 60 specimens) possess one dorsal, triangle-shaped process (Figure 3C). Twenty percent of the surveyed island females bear large egg sacs with 23-30 eggs (Figure 3D), whereas continental females did not bear egg sacs. 

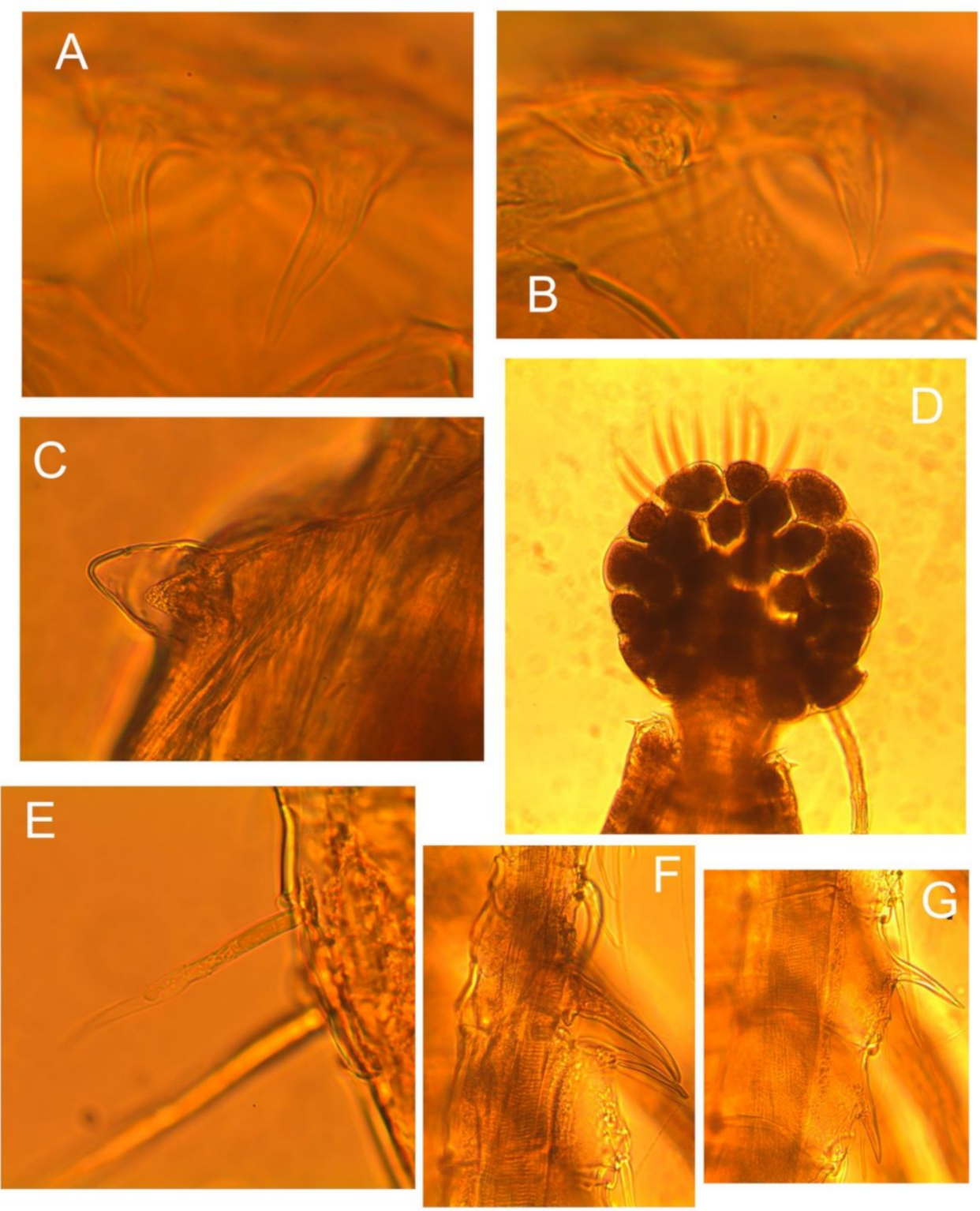

Figure 3. Mastigodiaptomus ha, adult female from 25 Horas Lagoon (island population): (A) large curved rostral spines; M. ha, adult female from Verde Lucero Lagoon (continental population): (B) short acute rostral spines; $M$. ha, adult female from 25 Horas Lagoon: (C) dorsal process, lateral view; (D) egg sac, dorsal view; (E) modified setae on antennulary segment 11. M. ha, adult male from 25 Horas Lagoon: (F) right antennule segments 13, 14; (G) same, segments 15, 16.

In M. ha, the presence of modified setae on both female and male antennules was notable as a distinctive feature; these setae are large, flattened, and distally expanded (Figure 3E). In the island population, the spines of male right antennulary segments 13-16 are proportionally larger than those of all the continental populations (Figure 3F-G).

\section{Discussion}

After systematic surveys of freshwater and anchialine zooplankton were conducted for approximately 15 years in the YP, including on Cozumel Island, this is the first finding on record of a freshwater, free-living calanoid diaptomid on a Mexican island. In the southern region of Cozumel Island where $M$. ha was collected, the pools are flooded in the rainy period (July to October) and the 25 Horas Lagoon suffers a reduced catchment area during the dry season (March to May), with a proportional decrease in the copepod's population. 
Therefore, it is hypothesised that $M . h a$ is an endemic form of some freshwater systems located in the north-northeastern regions of the YP, and is probably present on other Caribbean islands with geological histories that are homologous to that of Cozumel Island.

The physiography of the YP has been influenced by successive marine regression and transgression processes: during the Cretaceous Period ( 145 Mya) and the Pleistocene Yarmouth interglacial stage (220-170 Kya, during which the sea level rose $30 \mathrm{~m}$ above the current level), the YP was submerged [7,25]. The YP and Cozumel have been separate since the early Cenozoic Era ( 65 MYa) [26]. Allopatric speciation has been advanced as a possible explanation for the divergence of two species of anchialine remipedes: Xibalbanus cozumelensis (island species) and X. tulumensis (continental). A weak gene flow between these two populations was deemed probable because the marine regressions likely gave place to intermittent communication between these populations, which is not the case for epigean freshwater crustaceans.

The eastern coast of the YP remained submerged for about 33 MY, between the Paleocene and Oligocene periods. During these periods of marine regression, freshwater forms could have recolonised the emerged lands. According to Suárez-Morales [7], one of these forms was an ancestor of the genus Mastigodiaptomus, probably related to $M$. albuquerquensis, currently deemed to represent a species complex. This ancestral form successfully radiated across the Yucatan Peninsula, including its central core and eastern coast [7]. The occurrence records of $M$. ha more or less seem to fit the area flooded by seas in the Pleistocene interglacial period, which suggests that this freshwater species could be relatively young $(<220-170 \mathrm{Kya})$.

The most recent soils on the coastal fringe of the peninsula were formed during the Pleistocene Epoch ( 1.8 Mya) and the Holocene Epoch (11 Kya) with predominant calcites and dolomites as the most common mineral (of organic origin) [27]. The current physiography of the YP (including its islands and its complex and extensive hypogean landscapes) was present approximately 8-6 Kya $[7,27,28]$. The specific natures (freshwater, anchialine, or strictly marine) of the cavernous ecosystems in the region were influenced by the intermittent drought/cold periods that took place between 8 and 7, and 6 and 5 Kya [7,28], called stadial and interstadial periods during the Holocene period ( 9 Kya). These dry and cold conditions in the YP during the Holocene period [29], the high reproductive rates in copepods, and phoresis of micro-crustaceans by birds [30], probably represented adequate conditions promoting the dispersal of epigean freshwater copepods through glacial refuges in emerged (probably cold lands), including the presence of $M$. ha in Cozumel Island and the eastern coast of the YP.

Additionally, the north and northeastern zones of the YP are considered to have low elevational contrasts, with plains lower than 20 masl, and these regions are apparently separated from the geologically older Meridional Peninsula by hills with elevation levels of 50 to 300 masl [31]. The groundwater ecosystems that span these plains are home to the greatest diversity of species and the highest number of endemic crustaceans in the YP [32]. In accordance with the distribution of other freshwater fauna, such as fish [33], the distribution of freshwater crustaceans that inhabit the plain region can apparently be explained by these geographic barriers.

The presence of $M$. $h a$ individuals in this region supports the hypothesis that the YP is the area with the greatest known diversity and with the highest endemism of the Mastigodiaptomus species in the Neotropical region, probably resulting from its habitat diversity and complex geologic history [2,7]. In the YP, seven diaptomid species have been recorded: Arctodiaptomus dorsalis (Marsh, 1907); Leptodiaptomus novamexicanus (Herrick 1895); M. nesus (Bowman, 1986); M. reidae (Suárez-Morales and Elías-Gutiérrez, 2000); M. maya (Suárez-Morales and Elías-Gutiérrez, 2000); M. siankaanensis (Mercado-Salas, Khodami, Kihara, Elías-Gutiérrez and Martínez-Arbizu, 2018), and M. ha (CervantesMartínez, 2020). The latter four are considered YP endemics [3,7,34]. The late Eocene marine regression exposed most of the YP [7]. This combination of geological, climatological, and 
ecological conditions probably promoted the isolation conditions for local crustacean speciation and its current distributional patterns in the area [7].

Because low genetic divergence was revealed in and between the analysed continental and island populations of $M$. $h a$, it is hypothesised that the island population did not result from a very recent invasion process by humans, who have occupied the Cozumel island since $300 \mathrm{BC}$ [35]. Instead, it is suggested that both the continental and island populations have an early common origin, and these populations were isolated after the Pleistocene Yarmouth interglacial stage; the slight morphological divergences featured, found within and between the examined populations of $M$. $h a$, support the previous statement, as well as a lack of evidence that the distribution of the Mastigodiaptomus species is promoted through resistance (or diapause) structures.

The genetic divergence found between populations was remarkably low, ranging between 0 and 2.22\%: among the Mastigodiaptomus species, the greatest differences recorded within populations reach $2.76 \%$ on average [2]. The relatively low genetic, inter- and intrapopulation divergences found in $M$. ha might indicate the young age of the species. These low divergences have been found in freshwater fish whose current distributional ranges were glaciated during the Pleistocene period in America [36], and are probably related to the reduced population size in glacial refuges causing bottlenecks [37].

Morphological variabilities were described among and within the continental populations of $M$. ha in their original description [3]. In this study, when the continental populations were compared with the island population, a morphological variation was observed in body size (with striking differences between females and males), the rostrum shape, and the size of the spiniform process of the male right antennulary segments 13-16.

In addition, the presence/absence of a dorsal process in females is a variable feature between and within populations of Mastigodiaptomus texensis, M. amatitlanensis, M. albuquerquensis, M. montezumae, and $M$. ha [38]. We speculate here that the variability of this character appears to be related to the presence of fish co-occurring with Mastigodiaptomus: the dorsal process is absent or very reduced in presence of predator fish, but mostly present and well-developed when fish predation is absent or negligible (unpublished data).

This is the third report of a Mastigodiaptomus species inhabiting Caribbean islands with an elevation below 100 masl: M. nesus was recorded on San Salvador Island, the Cayman Islands, the Bahamas, and Cuba; M. purpureus in Cuba [39], and M. ha in Cozumel (this report). Five species of this genus have been recorded at altitudes $\geq 1000$ masl: M. montezumae [40], M. patzcuarensis, M. albuquerquensis [3,41], M. suarezmoralesi [38], and M. amatitlanensis [3]. It is likely that the ability of diaptomid genera to dwell in wide elevation and latitudinal ranges is a factor promoting the high regional diversity of Mastigodiaptomus.

Individuals of Mastigodiaptomus that inhabit island populations appear to be larger on average than their continental counterparts; for instance M. purpureus, exclusively recorded in Cuba, is one of the largest species (females $=2.5 \mathrm{~mm}$ long, males $=2.2 \mathrm{~mm}$ ) $[42,43]$. The length of M. nesus in Cuban populations is $1.48 \mathrm{~mm}$ in females, and 1.34 in males [39] vs. $0.9-1.0 \mathrm{~mm}$ in both sexes in the continental populations [3,44]; the length of $M$. ha from Cozumel is $1.73 \mathrm{~mm}$ in females and $1.5 \mathrm{~mm}$ in males vs. $1.2-1.3 \mathrm{~mm}$ in both sexes in the YP continental populations [3]. As discussed above, it is likely that the presence of fish is related to decreasing copepod size, because in all mentioned cases in which larger island specimens occur, fish are absent.

\section{Conclusions}

After almost two decades of basic study on freshwater and anchialine zooplankton on Cozumel Island, this is the first report on Mastigodiaptomus ha (Cervantes-Martínez, 2020), a freshwater, free-living diaptomid copepod on a Mexican island.

This copepod was previously recorded in freshwater continental ecosystems on the north and northeastern region of the continental plate of the YP; this region is historically 
and geologically similar to Cozumel Island, and slight morphologic and genetic differences were found between the continental and the island populations of M. ha.

Because low genetic divergences were observed between the analysed continental and island $M$. ha populations, both populations of the species probably resulted from the same founder effect.

The YP is the region in which the greatest number of copepod inventories has been documented and the greatest known diversity of the Mastigodiaptomus species has been confirmed among the central and northern regions of Mexico, Central America and the Caribbean.

Finally, analyses combining morphological and genetic characteristics in the continental populations of freshwater copepods (and other zooplankton groups) are still scarce. These kinds of studies are even more rare for insular, freshwater organisms. Our study is the first work in Mexico and the Caribbean region, which combined the genetic and morphological tools in research on the freshwater copepod diversity in insular freshwater bodies.

Author Contributions: Conceptualisation, A.C.-M.; methodology, A.C.-M., M.A.G.-A., E.S.-M. and S.J.; software, S.J.; validation, A.C.-M. and E.S.-M.; formal analysis, A.C.-M., M.A.G.-A., E.S.-M. and S.J.; investigation, A.C.-M., M.A.G.-A., E.S.-M. and S.J.; resources, A.C.-M., M.A.G.-A., E.S.-M. and S.J.; data curation, A.C.-M., M.A.G.-A., E.S.-M. and S.J.; writing-original draft preparation, A.C.-M. and M.A.G.-A.; writing-review and editing, M.A.G.-A.; visualisation, A.C.-M., M.A.G.-A., E.S.-M. and S.J.; supervision, A.C.-M.; project administration, A.C.-M.; funding acquisition, A.C.-M. All authors have read and agreed to the published version of the manuscript.

Funding: This research received no external funding.

Institutional Review Board Statement: We collected from several freshwater ecosystems in Mexico. Zooplankton is not under any protection by Mexican laws; thus, no specific permits for this type of field studies are needed.

Informed Consent Statement: Not applicable.

Data Availability Statement: All sequences the public dataset with the name Mastigodiaptomus was created in BOLD database and is avaiable in: DOI: 10.5883/DS-MMASTIGO.

Acknowledgments: The specimens deposited in the Collection of Zooplankton at El Colegio de la Frontera Sur (ECOSUR) were catalogued by R.M. Hernández and J.A. Cohuó-Colli. Mexican Barcode of Life (MEXBOL) provided support for genetic analysis. Facilities to genetic analysis were provided by Barcoding Laboratory of Life, and A. García-Morales (ECOSUR). We are grateful for the academic language editing provided by native English speakers, as well as to the Academic Group Vulnerabilidad y Biodiversidad de Sistemas Acuáticos Continentales y Costeros at the University of Quintana Roo. Three anonymous reviewers improved the manuscript.

Conflicts of Interest: The authors declare no conflict of interest.

\section{References}

1. Marsh, C.D. A revision of the north American species of Diaptomus. Trans. Wis. Acad. Sci. Arts Lett. 1907, 15, 381-516.

2. Mercado-Salas, N.F.; Khodami, S.; Kihara, T.C.; Elías-Gutiérrez, M.; Martínez-Arbizu, T. Genetic structure and distributional patterns of the genus Mastigodiaptomus (Copepoda) in Mexico, with the description of a new species from Yucatan Peninsula. Arthropod Syst. Phylogeny 2018, 76, 487-507.

3. Gutiérrez-Aguirre, M.A.; Cervantes-Martínez, A.; Elías-Gutiérrez, M.; Lugo-Vázquez, A. Remarks on Mastigodiaptomus (Calanoida: Diaptomidae) from Mexico using integrative taxonomy, with a key of identification and three new species. PeerJ 2020, 8 , e8416. [CrossRef]

4. Cervantes-Martínez, A.; Gutiérrez-Aguirre, M.A.; Delgado-Blas, V.H.; Ruiz-Ramírez, J.D. Especies del Zooplancton Dulceacuícola de Cozumel, 2nd ed.; Universidad de Quintana Roo: Quintana Roo, Mexico, 2018; pp. 1-64.

5. Suárez-Morales, E.; Cervantes-Martínez, A.; Gutiérrez-Aguirre, M.A.; Iliffe, T.M. A new Speleophria (Copepoda, Misophrioida) from an anchialine cave of the Yucatan Peninsula with comments on the biogeography of the genus. Bull. Mar. Sci. 2017, 93, 863-878. [CrossRef] 
6. Suárez-Morales, E.; Gutiérrez-Aguirre, M.A.; Cervantes-Martínez, A.; Iliffe, T.M. A new anchialine Stephos Scott from the Yucatan Peninsula with notes on the biogeography and diversity of the genus (Copepoda, Calanoida, Stephidae). Zookeys 2017, 67, 1-17. [CrossRef]

7. Suárez-Morales, E. Historical biogeography and distribution of the freshwater calanoid copepods (Crustacea: Copepoda) of the Yucatan Peninsula, Mexico. J. Biogeogr. 2003, 30, 1851-1859. [CrossRef]

8. Perry, E.; Velazquez-Oliman, G.; Marin, L. The Hydrogeochemistry of the Karts Aquifer System of the Northern Yucatan Peninsula, Mexico. Int. Geol. Rev. 2002, 44, 191-221. [CrossRef]

9. Cervantes-Martinez, A.; Elías-Gutiérrez, M.; Suárez-Morales, E. Limnological and morphometrical data of eight karstic systems "cenotes" of the Yucatan Peninsula, Mexico, during dry season (February-May, 2001). Hidrobiologia 2002, 482, 167-177. [CrossRef]

10. Cervantes-Martínez, A. El balance hídrico en cuerpos de agua cársticos de la Península de Yucatán. Teor. Prax. 2007, 3, 143-152. [CrossRef]

11. Cervantes-Martínez, A. Estudios limnológicos en sistemas cársticos (cenotes). In Biodiversidad Acuática de la Isla de Cozumel; Mejía-Ortíz, L., Ed.; Plaza y Valdéz: Ciudad de México, Mexico, 2008; pp. 349-358.

12. Yáñez-Mendoza, G.; Zarza-González, E.; Mejía-Ortiz, L.M. Sistemas anquialinos. In Biodiversidad Acuática de la Isla de Cozumel; Mejía-Ortíz, L., Ed.; Plaza y Valdéz: Ciudad de México, Mexico, 2008; pp. 49-69.

13. Suárez-Morales, E.; Reid, J.W. An updated checklist of the continental copepod fauna of the Yucatan Peninsula, Mexico, with notes on its regional associations. Crustaceana 2003, 76, 977-991. [CrossRef]

14. CONAGUA, Comisión Nacional del Agua. Available online: https://smn.conagua.gob.mx/files/pdfs/comunicados-de-prensa/ Comunicado444-20.pdf (accessed on 7 May 2021).

15. Elías-Gutiérrez, M.; Suárez-Morales, E.; Gutiérrez-Aguirre, M.A.; Silva-Briano, M.; Granados-Ramírez, J.G.; Garfias-Espejo, T. Cladocera y Copepoda de Las Aguas Continentales de México. Guía Ilustrada; CONABIO, UNAM: Ciudad de México, Mexico, 2008; pp. $1-322$.

16. Suarez-Morales, E.; Gutiérrez-Aguirre, M.A.; Gómez, S.; Perbiche-Neves, G.; Previattelli, D.; dos Santos-Silva, N.; da Rocha, C.E.F.; Mercado-Salas, N.F.; Marques, T.M.; Cruz-Quintana, Y.; et al. Class Copepoda. In Thorp and Covich's Freshwater Invertebrates: Keys to Neotropical and Antarctic Fauna; Damborenea, C., Rogers, C.D., James, T., Eds.; Elsevier Science Publishing Co., Inc.: San Diego, CA, USA, 2020; Volume 5, pp. 1-1046.

17. Suárez-Morales, E.; Elías Gutiérrez, M. Two new Mastigodiaptomus (Copepoda: Diaptomidae) from southeastern Mexico, with a key for the identification of the known species of the genus. J. Nat. Hist. 2000, 34, 693-708. [CrossRef]

18. Gutiérrez-Aguirre, M.; Cervantes-Martínez, A. A new species of Mastigodiaptomus Light 1939 from Mexico, with notes of species diversity of the genus (Copepoda, Calanoida, Diaptomidae). Zookeys 2016, 631, 61-79. [CrossRef]

19. Ivanova, N.V.; Dewaard, J.R.; Hebert, P.D.N. An inexpensive automation-friendly protocol for recovering high-quality DNA. Mol. Ecol. Notes 2006, 6, 998-1002. [CrossRef]

20. Hebert, P.D.; Cywisnka, A.; Ball, S.L.; DeWard, J.R. Biological identification through DNA barcodes. Proc. Biol. Sci. 2003, 270, 313-321. [CrossRef]

21. Prosser, S.; Martínez-Arce, A.; Elías-Gutiérrez, M. A new set of primers for COI amplification from freshwater microcrustaceans. Mol. Ecol. Res. 2006, 13, 693-708. [CrossRef]

22. Elías-Gutiérrez, M.; Valdéz-Moreno, M.; Topan, J.; Young, M.R.; Cohuo-Colli, J.A. Improved protocols to accelerate the assembly of DNA barcode reference libraries for freshwater zooplankton. Ecol. Evol. 2018, 8, 3002-3018. [CrossRef]

23. Hall, F.G. Physical and chemical survey of cenotes of Yucatan. In The Cenotes of Yucatan: A Zoological and Hydrographics Survey; Pearse, A.S., Creaser, E.P., Hall, F.G., Eds.; Carnegie Inst.: Washington, DC, USA, 1936; p. 304.

24. Gondwe, B.R.N.; Lerer, S.; Stisen, S.; Marín, L.; Rebolledo-Vieyra, M.; Merediz-Alonso, G.; Bayer-Gottwein, P. Hydrogeology of the south-eastern Yucatan Peninsula: New insights from water level measurements, geochemistry, geophysics and remote sensing. J. Hydrol. 2010, 389, 1-17. [CrossRef]

25. Fiers, F.; Reid, J.W.; Iliffe, T.M.; Suárez-Morales, E. New hypogean cyclopoid copepods (Crustacea) from the Yucatan Peninsula, Mexico. Contrib. Zool. 1996, 66, 65-102. [CrossRef]

26. Olesen, J.; Meland, K.; Glenner, H.; Van Hengstum, P.J.; Iliffe, T.M. Xibalbanus cozumelensis, a new species of Remipedia (Crustacea) from Cozumel, Mexico, and a molecular phylogeny of Xibalbanus on the Yucatan Peninsula. Eur. J. Taxon. 2017, 316, 1-27. [CrossRef]

27. Lugo-Hubp, J.J.; Aceves-Quesada, F.; Espinasa-Pereña, R. Rasgos geomorfológicos mayores de la península de Yucatán. Rev. Mex. Cienc. Geol. 1992, 10, 143-150.

28. Weide, A.E. Geology of the Yucatan Platform. In Geology and Hydrogeology of the Yucatán and Quaternary Geology of Northeastern Yucatan Peninsula; Ward, W.C., Weidie, A.E., Back, W., Eds.; Geological Society: New Orleans, LA, USA, 1985; pp. 1-19.

29. Leyden, B.W.; Brenner, M.; Hodell, D.A.; Curtis, J.H. Late Pleistocene climatic in the Central American lowlands. In Climatic Change in Continental Isotopic Records; Swart, P.K., Lohmann, K.C., Mckenzie, J., Savin, S., Eds.; Geophysical Monograph Series; AGU: Washington, DC, USA, 1993; pp. 165-178. [CrossRef]

30. Cortés-Ramírez, G.; Gordillo-Martínez, A.; Navarro-Sigüenza, G. Patrones biogeográficos de las aves de la península de Yucatán. Rev. Mex. Biodivers. 2012, 83, 530-542. [CrossRef]

31. López Ramos, E. Estudio geológico de la Península de Yucatán. Assoc. Mex. Geol. Pet. Bol. 1973, 25, $23-76$. 
32. Álvarez, F.; Iliffe, T.; Benítez, S.; Brankovits, D.; Villalobos, J.L. New records of anchialine fauna from the Yucatan Peninsula, Mexico. Check List 2015, 11, 1-10. [CrossRef]

33. Schmitter-Soto, J. Ichthyogeography of Yucatan, Mexico. In Libro Jubilar en Honor al Dr. Salvador Contreras Balderas; Lozano-Vilano, M.L., Ed.; Universidad Autónoma de Nuevo León: Monterrey, Mexico, 2004; pp. 103-116.

34. Brandorff, G.-O. Distribution of some Calanoida (Crustacea: Copepoda) from the Yucatán Peninsula, Belize and Guatemala. Rev. Biol. Trop. 2012, 60, 187-202. [CrossRef]

35. Cuarón, A.D. Cozumel. In Encyclopedia of Islands; Gillespie, R., Clague, D., Eds.; University of California Press: Berkeley, CA, USA, 2009; pp. 203-206.

36. Avise, J.C.; Bermingham, E.; Kessler, L.G.; Saunders, C. Characterization of mitochondrial DNA variability in a hybrid swam between subspecies of bluegill sunfish (Lepornis macrochirus). Evolution 1984, 38, 931-941.

37. Billington, N.; Hebert, P.D.N. Mitochondrial DNA diversity in fishes and its implications for introductions. Can. J. Fish. Aquat. Sci. 1991, 48, 80-94. [CrossRef]

38. Gutiérrez-Aguirre, M.A.; Cervantes-Martínez, A. Diversity of freshwater copepods (Maxillopoda: Copepoda: Calanoida, Cyclopoida) from Chiapas, Mexico with a description of Mastigodiaptomus suarezmoralesi sp. nov. J. Nat. Hist. 2013, 47, 479-498. [CrossRef]

39. Bowman, T.E. Freshwater calanoid copepods of the West Indies. Syllogeus 1986, 58, 237-246.

40. dos Santos-Silva, E.N.; Elías-Gutiérrez, M.; Silva-Briano, M. Redescription and distribution of Mastigodiaptomus montezumae (Copepoda, Calanoida, Diaptomidae) in Mexico. Hydrobiologia 1996, 328, 207-213. [CrossRef]

41. Gutiérrez-Aguirre, M.A.; Cervantes-Martínez, A.; Elías-Gutiérrez, M. An example of how barcodes can clarify cryptic species: The case of the calanoid copepod Mastigodiaptomus albuquerquensis (Herrick). PLoS ONE 2014, 9, e85019. [CrossRef] [PubMed]

42. Wilson, M.S.; Yeatman, H.C. Free-living Copepoda. In Ward's \& Whipple's Freshwater Biology; Edmonson, W.T., Ed.; John Wiley \& Sons, Inc.: New York, NY, USA, 1959; pp. 735-861.

43. Mitch, K.; Fernando, C.H. The freshwater calanoid and cyclopoid copepod Crustacea of Cuba. Can. J. Zool. 1978, 56, $2015-2023$.

44. Cervantes-Martínez, A.; Elías-Gutiérrez, M.; Gutiérrez-Aguirre, M.A.; Kotov, A. Ecological remarks on Mastigodiaptomus nesus Bowman, 1986 (Copepoda: Calanoida) in a Mexican karstic sinkhole. Hydrobiology 2005, 542, 95-102. [CrossRef] 